\title{
High intensity interval training with body weight: the new calisthenics?
}

\author{
Alexandre F. Machado', Rodolfo de Alkmim Moreira Nunes², Rodrigo Gomes de Souza Vale², \\ Roberta Luksevicius Rica ${ }^{3}$, Aylton Figueira Junior', Danilo Sales Bocalini ${ }^{4}$
}

\begin{abstract}
Background: Physical training based on body weight was practiced by the Roman military in ancient Rome. The use of old calisthenics has been reproduced with high-intensity interval training in several studies in the last years. Objective: The aim of this study is to do a review to identify the variables of calisthenics applied with high-intensity interval training method with the purpose of suggesting a strategy to apply in the training sessions. Method/Design: The search was conducted in MEDLINE, EMBASE, SciELO (Scientific Electronic Library Online), LILACS (Literatura Latino-americana e do Caribe em Ciências da Saúde [Centro Latinoamericano y del Caribe de Información en Ciencias de la Salud]), PUB MED CENTRAL, and Cochrane Central Register of Controlled Trials databases. Results: From the results, common points in the prescription of calisthenic HIIT with regard to "all out" load are observed. Conclusion: Based on the review results, it is suggested a guideline based on a single stimulus time of 30 seconds and differentiated recovery time for different practitioner profiles, as well as regarding the selection of exercises.
\end{abstract}

Keywords: HIIT; Prescription; Physical Exercise; Bodyweight; Training.

\section{INTRODUCTION}

Although physical exercise with body weight was already practiced in ancient Rome for war purposes, it was only in 1785 that physical exercises with body weight integrated in physical education ${ }^{(1,2)}$. Conceptually, calisthenics is a practice of rhythmic exercises without instruments called "free exercises"(3). According to Alijas and Torre ${ }^{(3)}$ in 1936 the three principles adopted for the structuring of Calisthenics were disclosed, they were: selection, precision and totality. Among them, the principle of totality was considered as the basis for the development of the reference table for calisthenics sessions with exercises distributed in three groups: introductory (warm-up exercises), fundamental (consisting of exercises of extension, flexion and lateral of trunk, balance, abs, runs and jumps) and conclusive (consisting of exercises "back to calm"). Some researchers have been using calisthenic exercises with high-intensity interval training (HIIT) and calling it calisthenics HIIT, new calisthenics or HIIT bodywork (HBW). Interestingly, there are still few studies with this type of approach, however, considering the few studies available in the literature it is possible to find different nomenclatures of the proposal, as follows: whole-body training ${ }^{(6)}$, whole-body calisthenics $^{(4,5)}$ and HIIT body work ${ }^{(2,7)}$. For teaching purposes, we use the expression "HIIT body work" as a synonym for these nomenclatures. Until the present moment there are no reports investigating which strategy should be applied to the protocol, considering the control of loads in the training and selection of exercises during the session of "HIIT body work".

There are few studies comparing adaptations to HIIT training with conventional training ${ }^{(4-9)}$, and also comparing it from the clinical viewpoint ${ }^{(8-9)}$. The load in the HIIT session is controlled by the types of movement or the time load, which is composed of the following variables: total session time, stimulus time, recovery time and the number of stimuli in the session (figure 1).

The training cycle in HIIT has been distributed in two approaches, with stimuli less than 1 minute and stimuli equal to or greater than 1 minute of duration ${ }^{(7,10,11)}$. Regarding the duration of the session in the HIIT protocols, are found variations of 4 and 45 minutes, duration of the stimulus between 20 seconds and 4 minutes and the recovery time between 10 seconds and 4 minutes ${ }^{(4-6,10,11)}$. In this way, using classic concepts of sports training ${ }^{(12,13)}$, the total session time and the stimulus-recovery relationship can be considered 
components of the training load. Figure 1. Example of exercises and their classification in function of the type of movement.

Conceptually, training load (TL) is the relationship between quantity and quality of work performed in a training session ${ }^{(10-11)}$. It is composed by time load and complexity of the exercises selected in the session and can be interpreted as internal and external load ${ }^{(12-13)}$. Considering the external load as the total number of movements performed in the HBW training session that characterizes the work performed during the session ${ }^{(14-15)}$.

The internal training load, which corresponds basically to the acute physiological responses provided by the exercise ${ }^{(15)}$, is related to the perception of effort, heart rate and maximal oxygen uptake (VO2max), parameters already frequently used as indicators of monitoring in the literature ${ }^{(12-14)}$. Table 1 shows the stimulus-recovery ratio of some classical studies ${ }^{(16-22)}$ using HIIT protocols. Considering the lack of studies on "HIIT body work", we intend to clarify about training variables that can be used during sessions of "HBW". TIME VARIABLES The HIIT Has

\begin{tabular}{|c|c|}
\hline & Classification \\
\hline Jumping Jack & Simple \\
\hline Burpee & Complex \\
\hline Mountain climber & Simple \\
\hline Squat thrust & Complex \\
\hline Squat & Simple \\
\hline Squat jump & Complex \\
\hline Split & Simple \\
\hline Alternate & Complex \\
\hline
\end{tabular}

Figure 1. Example of exercises according to the complexity of the motor gesture. been used as an efficient strategy for those who seek weight loss and conditioning quickly and efficiently ${ }^{(8,17)}$.

However, the lack of a specific protocol for "HBW" may prevent the development and use of this strategy for this purpose. Gray ${ }^{(23)}$ states that HIIT is a methodology for accessing most people because it is simple and low cost, HBW fits perfectly into these characteristics, but the use of this powerful tool requires a methodological mastery by the professionals for a safe and efficient prescription.

Some studies ${ }^{(4-6)}$ available in the literature that used the "HBW" had been used pattern of "all out" load control with stimulus time, recovery time and total duration of the session quite varied.

The "all out" method is characterized as the maximal intensity possible during the proposed stimulus period ${ }^{(17)}$. Although the relationship of TL and the level of physical fitness in HBW, the volunteers should try to do the highest number of repetitions of the movement as possible within the stimulus period proposed ${ }^{(7,23)}$.

In this perspective, it is possible to consider that the TL can be manipulated, increasing or decreasing the stimulation or recovery time during the training cycles for different profiles of practitioners (beginners, intermediate and advanced) for an organization of the training session considering the time and motor experience in the modality as well as the level aptitude, strategy already used in other studies ${ }^{(23-25)}$. For a simple organization of the training sessions of "HBW" it is possible to consider that the use of TL with less physiological impact is recommended for beginners, and the recovery time must be longer than the stimulus time. In intermediate individuals is possible to consider TL with greater physiological impact, and the recovery time can be equal to the stimulus time. And for individuals with an advanced profile the TL may be more intense, it is possible with a recovery time lower than the stimulus time ${ }^{(7)}$. In addition, another parameter that deserves attention in this discussion refers to the selection of the exercises used during the sessions of "HBW".

\section{EXERCISE SELECTION}

The exercise selection during the session of "HBW" is another crucial parameter to the success of the training program $^{(6,10)}$, mainly due to the complexity of the motor

Table 1. Stimulus-recovery ratio and total time in HIIT protocols.

\begin{tabular}{lccc}
\hline & $\begin{array}{c}\text { Stimulus } \\
\text { time }\end{array}$ & $\begin{array}{c}\text { Recovery } \\
\text { time }\end{array}$ & $\begin{array}{c}\text { Total duration of the } \\
\text { session }\end{array}$ \\
\hline Tabata et al. ${ }^{(16)}$ & $20 \mathrm{sec}$ & $10 \mathrm{sec}$ & $4 \mathrm{~min}$ \\
Gibalaet al. $^{(17)}$ & $30 \mathrm{sec}$ & $4 \mathrm{~min}$ & 18 a $27 \mathrm{~min}$ \\
Osamwet al. ${ }^{(18)}$ & $1 \mathrm{~min}$ & $1 \mathrm{~min}$ & $30 \mathrm{~min}$ \\
Tucker et al. $^{(19)}$ & $4 \mathrm{~min}$ & $4 \mathrm{~min}$ & $28 \mathrm{~min}$ \\
Tucker et al. $^{(20)}$ & $1 \mathrm{~min}$ & $1 \mathrm{~min}$ & $32 \mathrm{~min}$ \\
Gillen et al. $^{(21)}$ & $20 \mathrm{sec}$ & $2 \mathrm{~min}$ & $45 \mathrm{~min}$ \\
Rozenek $^{(22)}$ & $1 \mathrm{~min}$ & $1 \mathrm{~min}$ & $20 \mathrm{~min}$ \\
\hline
\end{tabular}


gesture $^{(24)}$, however, there are no studies that investigated the effect of exercise selection on metabolic indicators as well as on the organization of training protocols. A simple and didactic way of classifying exercises refers to the pattern of movement ${ }^{(24,25)}$. Considering this approach we can distribute the exercises into two groups: exercises with a single pattern of movement (simple) and exercises with combined movement patterns (complex) (Figure 1). According to previous studies ${ }^{(25-28)}$, the execution of complex exercises requires higher energy expenditure ${ }^{(25-27)}$ and higher metabolic demand ${ }^{(26,28)}$. This characteristic can affect the dynamics of the training session considering the quality of the motor gestures, the fatigue and the total energy expenditure of the sessions of "HBW"(25-29). Thus, based on the proposed classification of movements, it is possible to consider three strategies for the selection of exercises. The first one corresponds to the selection of exercise with less physiological impact, characterized by exercises with simple pattern. The second corresponds to the selection of exercises considering the combination of movement patterns, therefore varying between simple and complex. The third strategy corresponds to the use of only exercises with complex pattern of movement (Figure 1). Table 1. Stimulus-recovery ratio and total time in HIIT protocols.

Stimulus time Recovery time Total duration of the session Tabata et al. ${ }^{(16)} 20 \mathrm{sec} 10 \mathrm{sec} 4 \mathrm{~min}$ Gibala et al. ${ }^{(17)} 30 \mathrm{sec} 4 \mathrm{~min}$ 18 a 27 min Osamw et al. ${ }^{(18)} 1 \mathrm{~min} 1 \mathrm{~min} 30 \mathrm{~min}$ Tucker et al. (19) 4 min 4 min 28 min Tucker et al. ${ }^{(20)} 1 \mathrm{~min} 1 \mathrm{~min} 32 \mathrm{~min}$ Gillen et al. ${ }^{(21)} 20 \sec 2 \mathrm{~min} 45 \mathrm{~min}$ Rozenek $^{(22)} 1 \mathrm{~min} 1 \mathrm{~min} 20 \mathrm{~min}$

Based on the data available in the literature, it is possible to visualize a basic guideline for the elaboration of a program of "HIIT body work" considering the parameters of TL using the "all out" load as internal parameter and the stimulus time, recovery time, total duration of the training session, selection and number of movements per exercise as external training load. A suggestion to monitor the internal load during and after the training session corresponds to the use of the subjective perception of effort with scores varying from 9 to 10 in the adapted scale of Borg independent of the level of physical aptitude and motor experience of the practitioner (table 2), a method already recognized for its specificity in monitoring during training sessions ${ }^{(30,31)}$.

Table 2. Proposed HIIT with body weight for different profiles physical aptitude.

\begin{tabular}{ccccccc}
\hline \multirow{2}{*}{ Profile } & \multicolumn{2}{c}{ External load } & & Internal load & \\
\cline { 2 - 3 } & $\begin{array}{c}\text { Time of } \\
\text { effort/ } \\
\text { recovery }\end{array}$ & $\begin{array}{c}\text { Session } \\
\text { duration } \\
(\mathrm{min})\end{array}$ & & $\begin{array}{c}\text { SPE } \\
\text { (score) }\end{array}$ & $\begin{array}{c}\text { Exercises } \\
\text { selection }\end{array}$ \\
\hline Beginner & $1: 2$ & 30 & & $9-10$ & \\
Intermediate & $1: 1$ & 30 & & $9-10$ & & $\begin{array}{c}\text { Simple and } \\
\text { Complex }\end{array}$ \\
Advanced & $1: 1 / 2$ & 30 & & $9-10$ & & Complex \\
\hline
\end{tabular}

SPE: subjective perception of effort ${ }^{(30)}$

\section{FINAL CONSIDERATIONS}

The "HIIT body work" can be considered an efficient and safe alternative, as long as it's working methodology is operationally feasible when applied in specific training environments such as: gyms, clubs, parks, studios and domicile. Although there is a need for further studies with diverse approaches including our methodology, we believe that the proposal presented in this study can be considered a simple approach for methodological organization of sessions of HIIT body work.

AFM: intellectual design, survey of references and writing; JRAMN: survey of references and review of article; RGSV: survey of references and review of article; AFJ: review of article; DSB: intellectual design and writing.

\section{CONFLICT OF INTEREST}

The authors declare no conflict of interest.

\begin{abstract}
2 Programa de Pós-Graduação em Exercício e Ciências do Esporte. Universidade Federal do Rio de Janeiro, Rio de Janeiro, RJ, Brasil

${ }^{3}$ Departamento de Educação Física. Universidade Estacio de Sá. Vitoria, ES, Brasil ${ }^{4}$ Laboratório de Fisiologia e Bioquímica Experimental. Universidade Federal do Espírito Santo, Vitoria, ES, Brasil.
\end{abstract}

\section{REFERÊNCIAS}

1- Azevedo CB, Santos RM. Corpo, criança e escola - aspectos da cultura escolar dos grupos escolares norte-rio-grandense. Mente - Revista de Humanidades. 2015; 16(37):91-126.

2- Clerk P, Crenn R, Listello A. Education Physique, pourtous. 1o edição. Paris, Editions Amphora; 1964.

3- Alijas RDR, Torre AHD. Calistenia: Volviendo a losorígenes. Emásf, Revista Digital de Educación Física, 2015. 6(33): 87-96.

4- Gist NH. et al. Effects of Low-Volume, High-Intensity Whole-Body Calisthenics on Army ROTC Cadets. Military medicine, 2015; 180 (5): 492-498.

5- Gist NH, Freese EC, Cureton KJ. Comparison of responses to two highintensity intermittent exercise protocols. The Journal of Strength \& Conditioning Research, 2014; (28)11:3033-3040.

6- Mcrae Gill et al. Extremely low volume, whole-body aerobic-resistance training improves aerobic fitness and muscular endurance in females. Applied Physiology, Nutrition, and Metabolism, 2012; (37)6:1124-1131.

7- Machado AF. HIIT manual prático. 1ํo edição, São Paulo, Editora Phorte; 2016.

8- Gibala MJ, Little JP. Just HIT it! A time-efficient exercise strategy to improve muscle insulin sensitivity. The Journal of physiology, 2010; (588)18: 33413342.

9- Gibala MJ, Gillen JB, Percival ME. Physiological and health-related adaptations to low-volume interval training: influences of nutrition and sex. Sports Medicine, 2014; (44) 2: 127-137.

10- Buchheit M, Laursen PB. High-intensity interval training, solutions to the programming puzzle. Sports medicine, 2013. (43) 5:313-338.

11- Buchheit M, Laursen PB. High-intensity interval training, solutions to the programming puzzle. Part II: anaerobic energy, neuromuscular load and practical apllications. Sports medicine, 2013. (43) 10: 927-954.

12- Borin JP, Prestes J, Moura NF. Caracterização, controle e avaliação: limitações e possibilidades no âmbito do treinamento desportivo. Revista Treinamento Desportivo, 2007. (8) 1: 6-11.

13- Borin JP, Gomes AC, Dos Santos Leite G. Preparação desportiva: aspectos do controle da carga de treinamento nos jogos coletivos. Revista da Educação Física/UEM, 2008. (18) 1: 97-105. 
14- Impellizzeri FM. et al. Physiologicaland performance effectsofgeneric versus specificaerobic training in soccer players. International journal of sports medicine, 2006 (27) 6: 483-492.

15- Pinho RW dos S, Braz TV, Cruz WA, Santos AB, Ribeiro C, Germano MD, Aoki MS, Lopes CR. Efeito da carga interna de treinamento sobre o VO2 MAX de mulheres adultas. R. Bras. Ci. e Mov, 2016; 24 (1):43-51.

16- Tabata I et al. Metabolic profile of high intensity intermittent exercises. Medicine and science in sports and exercise, 1997. (29)3: 390-395.

17- Gibala MJ, Mcgee SL. Metabolic adaptations to short-term high-intensity interval training: a little pain for a lot of gain? Exercise and sport sciences reviews, 2008. (36) 2: 58-63.

18- Osawa $Y$ et al. Effects of 16-week high-intensity interval training usin gupper and lower body ergometer son aerobic fitness and morphologic al changes in health y men: a preliminary study. Open access jornal of sports medicine, 2014. 5: 257, 2014.

19- Tucker WJ. et al. Physiological Responses to High-Intensity Interval Exercise Differing in Interval Duration. The Journal of Strength \& Conditioning Research, 2015. (29) 12: 3326-3335.

20- Tucker WJ, Angadi SS, Gaesser GA. Excess post exercise oxygen consumption after high-intensity and sprint interval exercise, and continuous steady-state exercise. Journal of strength and conditioning research / National Strength \& Conditioning Association, 2016 (21) 9: 326-339.

21- Gillen JB. et al. Twelve Weeks of Sprint Interval Training Improves Indices of Cardio metabolic Health Similar to Traditional Endurance Training despite a Five-Fold Lower Exercise Volume and Time Commitment. Plo Sone, 2016. (11) 4, e0154075.

22- ROZENEK, Ralph et al. Acute Cardiopulmonary and Metabolic Responses To High-Intensity Interval Training (Hiit) Protocols using 60s of work and 60s Recovery. The Journal of Strength \& Conditioning Research, (2016).

23- Gray SR. et al. High-intensity interval training: key data needed to bridge the gap from laboratory to public health policy. British Journal of Sports Medicine. 2016, bjsports-2015-095705.
24- Semenick DM, Adams KO. Sports performance series: The vertical jump: a kinesiological analysis with recommendations for strength and conditioning programming. Strength \& Conditioning Journal, 1987. (9) 3 : 5-11.

25- Amorim PRS, Faria FR. Dispêndio energético das atividades humanas e sua repercussão para a saúde/Energy expenditure of human activities and its impacton health. Motricidade, 2012. (8) S2: 295.

26- De Aguiar RA et al. Efeito da intensidade do exercício de corrida intermitente 30s: 15s no tempo de manutenção no ou próximo do VO2max. Motriz rev. educ. fís.(Impr.), 2013, (19) 1: 207-216.

27- De Moura Simim MA. Comportamento da frequência cardíaca, percepção subjetiva do esforço, e o gasto calórico durante uma sessão de circuito com pesos. Revista Brasileira de Prescrição e Fisiologia do Exercício (RBPFEX), 2011, (4) 21: 1.

28- Garcia NM. et al. Acquisition of Multiple Physiological Parameters During Physical Exercise. Digital Advances in Medicine, E-Health, and Communication Technologies, 2013: 102.

29- Fernandez-Fernandez J et al. acute physiological responses during crossfit $^{\circledR}$ workouts. European Journal of Human Movement, 2015. 35:1-25.

30- BORG G. Psycophysical bases of perceived exertion. Medicine and Science in Sports and Exercise, 1982, 14: 377- 81.

31- Burnetto AF, Elaine P, Yamaguti WPS. Comparação entre a escala de Borg modificada e a escala de Borg modificada análogo visual aplicadas em pacientes com dispnéia. Rev Bras Fisioter. 2002: 41-5.

32- Calil A et al. Estimativa do Limiar de Conconi por meio da Escala de Borg em cicloergômetro. Fitness \& performance jornal. 2005: 215-219.

33- Guimarães GV et al. Pode o teste ergoespirométrico de caminhada de seis minutos ser representativo das atividades habituais de pacientes com insuficiência cardíaca. Arq Bras Cardiol 2002, 78: 553-6.

34- Neves ARM, Leonice AD. Avaliação da percepção subjetiva de esforço e da freqüência cardíaca em mulheres adultas durante aulas de hidroginástica. Rev. bras. cineantropom. desempenho hum. 2007:9-4.

35- Nakamura FY et al. Utilização do esforço percebido na determinação da velocidade crítica em corrida aquática. Rev Bras Med Esporte. 2005, 11: $1-5$. 